\title{
Host DNA integrity within blood meals of hematophagous larval gnathiid isopods (Crustacea, Isopoda, Gnathiidae)
}

\author{
Gina C. Hendrick ${ }^{1,2}$, Maureen C. Dolan ${ }^{1,2}$, Tanja McKay $^{1}$ and Paul C. Sikkel ${ }^{1 *}$ (i)
}

\begin{abstract}
Background: Juvenile gnathiid isopods are common ectoparasites of marine fishes. Each of the three juvenile stages briefly attach to a host to obtain a blood meal but spend most of their time living in the substrate, thus making it difficult to determine patterns of host exploitation. Sequencing of host blood meals from wild-caught specimens is a promising tool to determine host identity. Although established protocols for this approach exist, certain challenges must be overcome when samples are subjected to typical field conditions that may contribute to DNA degradation. The goal of this study was to address a key methodological issue associated with molecular-based host identification from free-living, blood-engorged gnathiid isopods - the degradation of host DNA within blood meals. Here we have assessed the length of time host DNA within gnathiid blood meals can remain viable for positive host identification.

Methods: Juvenile gnathiids were allowed to feed on fish of known species and subsets were preserved at 4-h intervals over $24 \mathrm{~h}$ and then every $24 \mathrm{~h}$ up to 5 days post-feeding. Host DNA extracted from gnathiid blood meals was sequenced to validate the integrity of host DNA at each time interval. DNA was also extracted from blood meals of wild-fed gnathiids for comparison. Attempts were also made to extract host DNA from metamorphosed juveniles.

Results: Using a cox1 universal fish primer set, known fish host DNA sequences were successfully identified for nearly $100 \%$ of third-stage juvenile gnathiid blood meals, digested for up to 5 days post-feeding. For second-stage juveniles, host identification was $100 \%$ successful when gnathiids were preserved within $24 \mathrm{~h}$ of collection. Fish hosts were positively identified for $69 \%$ of sequences from wild-fed gnathiid isopods. Of the $31 \%$ of sequences not receiving a $\geq 98 \%$ match to a sequence in GenBank, 25 sequences were of possible invertebrate origin.

Conclusions: To our knowledge, this is the first study to examine the degradation rate of gnathiid isopod blood meals. Determining the rate at which gnathiids digest their blood meal is an important step in ensuring the successful host identification by DNA-based methods in large field studies.
\end{abstract}

Keywords: Marine parasite, DNA degradation, Blood meal analysis, cox1 barcoding

\section{Background}

Parasites are highly diverse organisms, found within every phylum and comprise approximately half of all living organisms [1-3]. The myriad of life history strategies of parasitic organisms (e.g. host specialists $v s$ host generalists; endoparasites $v s$ ectoparasites) complicates the

\footnotetext{
*Correspondence: psikkel@astate.edu

1 Department of Biological Sciences, Arkansas State University, State University, AR 72467, USA

Full list of author information is available at the end of the article
}

assessment of host-exploitation patterns in ecological communities. The act of parasitism influences individual hosts by affecting growth, behavior, and reproductive success [4] and therefore impacts population and community dynamics $[3,5,6]$. Thus, understanding patterns of exploitation of hosts by parasites is essential for understanding host populations and community processes.

Among ectoparasites of vertebrates, hematophagous, or blood-feeding, arthropods are perhaps the best-known and most thoroughly studied. Feeding on blood and other bodily fluids of their hosts, these organisms can impact

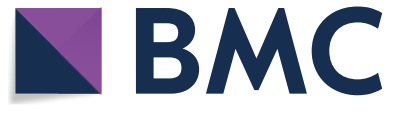

(c) The Author(s) 2019. This article is distributed under the terms of the Creative Commons Attribution 4.0 International License (http://creativecommons.org/licenses/by/4.0/), which permits unrestricted use, distribution, and reproduction in any medium, provided you give appropriate credit to the original author(s) and the source, provide a link to the Creative Commons license, and indicate if changes were made. The Creative Commons Public Domain Dedication waiver (http://creativecommons.org/ publicdomain/zero/1.0/) applies to the data made available in this article, unless otherwise stated. 
hosts by removal of vital fluids and facilitating infection [7]. Many are also vectors for pathogenic blood parasites, viruses, and bacteria. The most notorious of these are certain species of mosquitoes and ixodid ticks [8-10]. For those that feed on multiple host species, it is particularly difficult to assess patterns of host exploitation, since one cannot rely solely on collection of parasites from hosts, as this could lead to a sampling bias based on the ability to capture and process hosts.

Gnathiid isopods are among the most common ectoparasites of marine fishes, found globally and at various depths [11-14], and thus likely exceed the biomass of ticks and mosquitoes combined. Gnathiids have been most extensively studied on coral reefs where they infect a wide range of coral reef fishes [15-17], are the primary food of cleaner fishes [18-21], and are known to be a driving factor in cleaning symbioses [21-24].

Gnathiids are known to feed on the blood of fishes during each of three juvenile stages [11, 12], but do not feed as adults. At each juvenile stage an unfed gnathiid, or zuphea (Z1-Z3), attaches to a single host to feed until engorged. This fed gnathiid, or praniza (P1-P3), digests the blood meal and molts, returning to the unfed zuphea form after the first and second feedings, and to adult after the third feeding (Fig. 1a).

Given that feeding only requires minutes to hours, and molting requires multiple days, gnathiids spend most of their life-cycle in the substrate, not attached to their host (the only exception to this may be species that feed on sharks, which may remain attached to hosts for long periods). Thus, like some terrestrial blood-feeding arthropods, the term "micropredator" may also be suitable [10, 25-27]. During their free-living stages, including fed (praniza) stages, gnathiids can be easily collected using lighted plankton traps [28].

DNA-based taxonomy and identification, a powerful tool incorporated into many current biomonitoring studies, has resulted in the discovery of new faunas [29]. Using DNA barcoding for species identification is becoming more accessible, reliable, and more widely adopted, supplanting traditional morphology-based species identification [30]. DNA barcoding typically targets haplotypic (maternally inherited) mitochondrial genes, such as cytochrome $c$ oxidase subunit 1 (cox 1 , COI or
MT-CO1), as these genes are conserved across animal taxa and a vast number of reference sequences are readily available in public databases [31]. The success in species identification using $\operatorname{cox} 1$ is largely due to a relatively fast rate of evolution of this gene, allowing for a more robust phylogenetic signal than any other mitochondrial gene [32].

The majority of studies related to interactions between blood-feeding arthropods and their hosts have focused on terrestrial species. Methodologies for DNA barcoding of hematophagous arthropod blood meals to identify hosts have been reported [31, 33, 34]. Specifically, the mitochondrial target gene cox 1 has been successfully used to identify hosts of a variety of blood-feeding arthropods, such as ticks, mosquitoes, and biting midges [33, 35]. In aquatic systems, the use of DNA barcoding to identify fish species is well established for purposes of identifying fishes caught for human consumption [36, 37]. DNA mini-barcodes of the cox 1 gene have been used to reproducibly identify fish species in heavily processed food products [36]. Furthermore, cox 1 DNA sequences for a wide variety of marine fishes are publicly available [38] and provide a valuable reference database.

A particular challenge that must be properly managed when analyzing parasite blood meal samples subject to field conditions is DNA degradation. Efforts to limit or mitigate the DNA degradation process is paramount to the successful amplification of host DNA and the accurate identification of the blood meal source [31, 39]. Therefore, maintaining DNA integrity in the blood meal of ectoparasites will likely be a product of environmental conditions during field collection, proper preservation, and the digestion rate of the specific parasite.

Understanding how long after feeding a blood meal will remain viable for host identification is crucial to efficiently identifying the hosts of field-collected, bloodfeeding arthropods. Determining a window of sample viability limits unnecessary sample processing costs. In this study, we assessed the integrity of host DNA within blood meals of the common Caribbean gnathiid, Gnathia marleyi, at multiple time intervals post-ingestion and established methods that enable reproducible host identification. Gnathia marleyi is thus far the only gnathiid species at our study sites and known to feed on at least 20

(See figure on next page.)

Fig. 1 Life-cycle of gnathiid isopods and a general workflow for establishing host DNA integrity over time from gnathiid blood meal. a The three stages of unfed juvenile zuphea are identified as Z1, Z2 and Z3. Upon feeding, these zuphea develop into first-stage (P1), second-stage (P2), and third-stage (P3) fed pranizae, respectively. The star indicates the points within the gnathiid's life-cycle where we assessed host DNA integrity within blood meals. b Fifty gnathiids of each stage were placed into one of three containers, each filled with approximately 5 I of seawater. Unfed gnathiids were allowed to feed on a fish overnight, under controlled conditions. The following morning, the fish were removed and the fed gnathiids (pranizae) were transferred to $50 \mathrm{ml}$ beakers filled with seawater. Pranizae were allowed to digest their blood meals up to 5 days post-feeding. All subsets were preserved in 100\% molecular grade ethanol, and at c $0,4,8,12,16$, and $24 \mathrm{~h}$ post-feeding, gnathiids were preserved in real time 
a
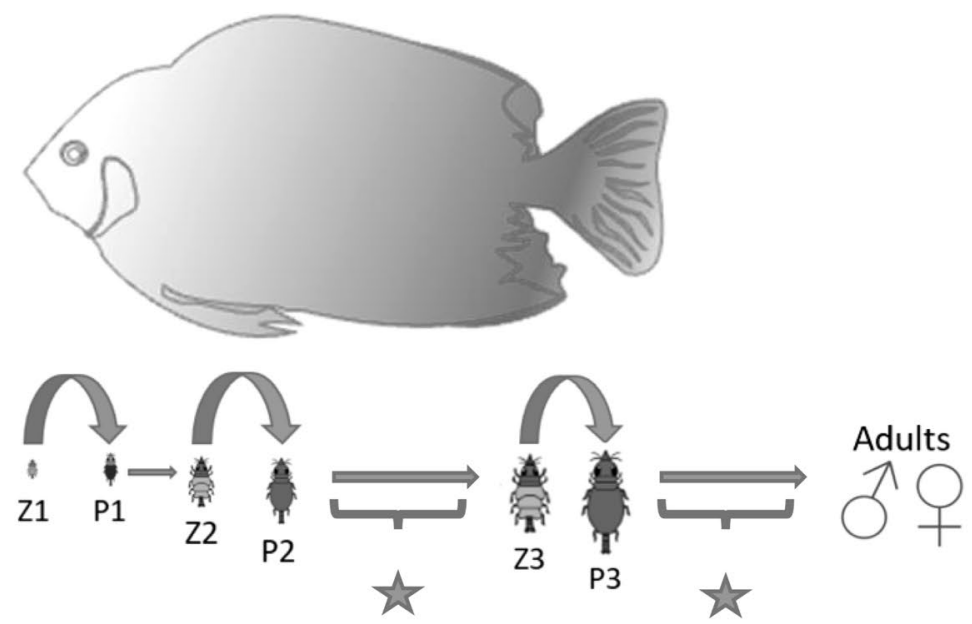

b
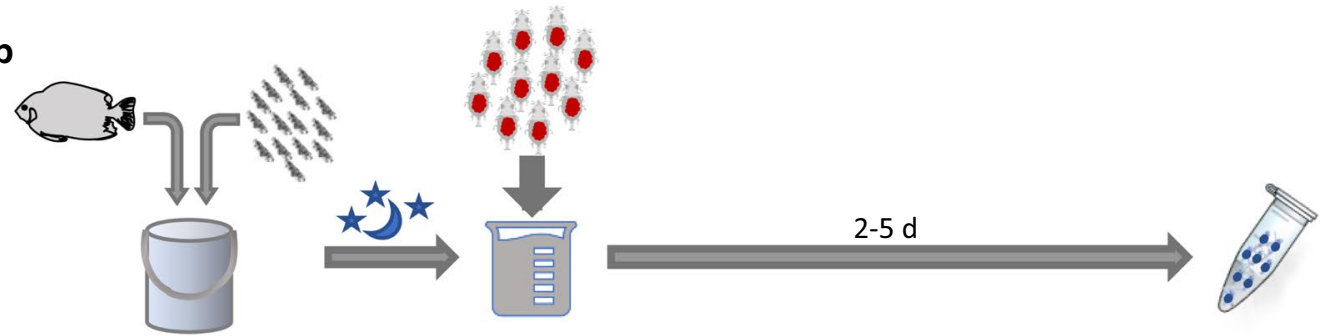

C
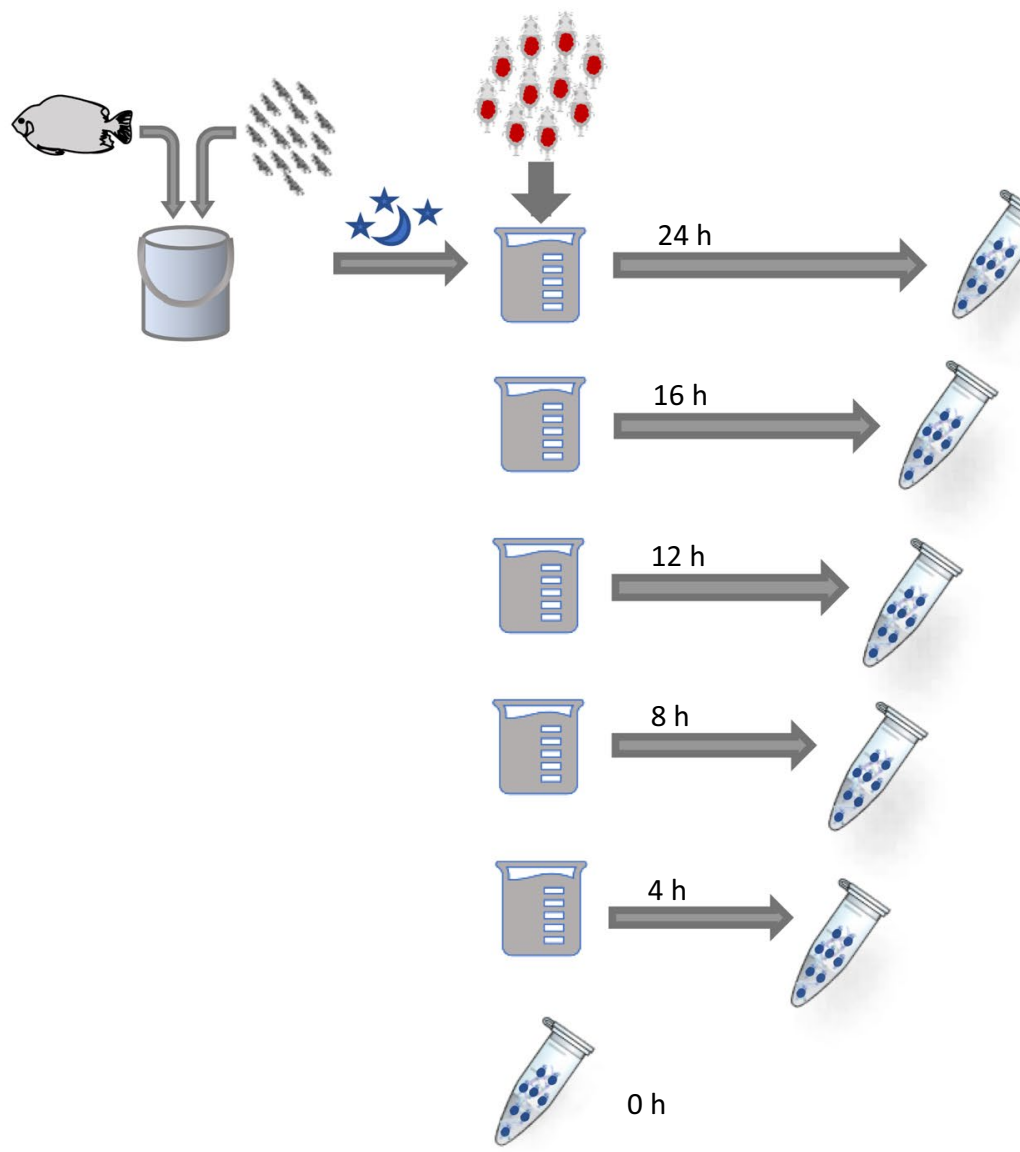
different host fishes $[17,40]$. This information will be key in establishing a standard operating procedure for the collection, processing, and accurate host species identification of gnathiids, ultimately to be incorporated into a robust biomonitoring approach for assessing coral reef health.

\section{Methods}

\section{Study species and field collection}

Gnathiids were collected between May and August of 2016 and 2017. All gnathiids were collected using lighted plankton traps, following the protocol established by Artim and Sikkel [28]. Light traps were deployed before dusk and allowed to remain on the reef until retrieval at dawn the following morning. The contents of each trap were filtered and sorted under a stereomicroscope to separate living juvenile gnathiid isopods from the collected plankton.

Two subsets of gnathiids were collected: (i) gnathiids used to determine known host DNA viability within digested blood meals over time were collected in Brewer's Bay, St. Thomas, United States Virgin Islands (USVI) $\left(18^{\circ} 20^{\prime} 25.3^{\prime \prime} \mathrm{N}, 64^{\circ} 58^{\prime} 36.8^{\prime \prime} \mathrm{W}\right)$. These gnathiids were preserved in $100 \%$ molecular grade ethanol at specific time points specified below; (ii) gnathiids used to validate molecular methods for processing wild-fed gnathiids with unknown hosts were collected off the coast of La Parguera, Puerto Rico $\left(17^{\circ} 57^{\prime} 18.1^{\prime \prime} \mathrm{N}, 67^{\circ} 03^{\prime} 08.1^{\prime \prime} \mathrm{W}\right)$. The latter were preserved in $100 \%$ molecular grade ethanol immediately upon sorting of plankton samples.

\section{Blood meal host DNA viability experimental design}

Unfed juvenile gnathiids (zuphea), retrieved from the lighted plankton traps in Brewer's Bay, St. Thomas and used to assess host DNA integrity in gnathiid blood meals, were kept in small containers filled with seawater for two days to assure that the gnathiids were starved. Fifty gnathiids of each stage (Z1-Z3) were placed into designated containers, each filled with approximately $5 \mathrm{l}$ of seawater. At dusk on the third day, each container of unfed gnathiids were allowed to feed overnight on a barred hamlet (Hypoplectrus puella) under controlled conditions (Fig. 1b, c). Water changes were performed daily.

To assess gnathiid host DNA integrity in blood meals between day 2 and day 5 post-feeding (Fig. 1b), each time point used newly starved gnathiids and a new host fish. Following an overnight feeding, gnathiids were removed from the containers, separated based on juvenile stage, and allowed to continue digesting their blood meal for designated post-feeding time. To asses host DNA integrity in blood meals over the first 24-h post-feeding period, fed gnathiids were collected and sorted into 6 subsets of 25 individuals, for both second- and thirdstage juveniles. These subsets were preserved in $100 \%$ molecular grade ethanol, at $0,4,8,12,16$, and 24 h postfeeding, in real time (Fig. 1c). The $0 \mathrm{~h}$ time point was set at 08:00 h. Gnathiids which had metamorphosed into adult males were also preserved and analyzed separately from the individuals still in their juvenile form.

All samples, preserved in ethanol, were maintained at $24{ }^{\circ} \mathrm{C}$ for $\leq 24 \mathrm{~h}$ prior to being placed on ice for shipment to Arkansas State University, Jonesboro, USA, and subsequently stored at $-20{ }^{\circ} \mathrm{C}$ until processing. All specimens were processed individually and at no time were samples pooled. First-stage pranizae were not used in this study due to their high mortality rate during handling, feeding, and filtering.

\section{Blood meal DNA extraction, cox1 amplification and sequencing}

DNA extraction, amplification, and sequencing methods were the same for both gnathiids used to identify unknown hosts $(n=100)$ and gnathiids used to assess host DNA integrity within blood meals $(n=252)$. DNA was extracted from whole, fed gnathiids using the PureLink $^{\circledR}$ Genomic DNA extraction kit (Invitrogen, Carlsbad, CA), in accordance with the manufacturers 'Mammalian Tissue and Mouse/Rat Tail Lysate' protocol. Briefly, specimens were removed from ethanol, placed on a Kimwipe to wick organic solvent from the specimen, immediately transferred to a $1.5 \mathrm{ml}$ microfuge tube with extraction solution and homogenized using a disposable Dounce homogenizer. Purified DNA was eluted using $\mathrm{dH}_{2} \mathrm{O}$ and was quantified using a NanoDrop ND-1000 UV/Vis spectrophotometer (Thermo Fisher Scientific, Wilmington, DE, USA). DNA quality and quantity of select samples were further confirmed by agarose gel electrophoresis $(1.5 \%$ agarose, $1 \times \mathrm{TBE})$ using a DNA low mass ladder (Invitrogen, Cat no. 10068-013). Select DNA samples were visualized using ethidium bromide staining.

For all second- and third-stage pranizae evaluated, $50 \mathrm{ng}$ of purified template DNA was used for each PCR amplification. Purified DNA was concentrated as needed using the ThermoSavant ISS110 SpeedVac ${ }^{\circledR}$ System (Thermo Fisher Scientific, Wilmington, DE, USA). PCR reactions were carried out using a Veriti 96 Well Thermal Cycler (Applied Biosystem, Foster City, CA, USA). Thermocycling conditions included an initial denaturation step of $94^{\circ} \mathrm{C}$ for $2 \mathrm{~min}$, followed by 30 cycles of $96^{\circ} \mathrm{C}$ for $20 \mathrm{~s}, 55^{\circ} \mathrm{C}$ for $20 \mathrm{~s}$, and $72{ }^{\circ} \mathrm{C}$ for $45 \mathrm{~s}$, with a final extension step of $72{ }^{\circ} \mathrm{C}$ for $7 \mathrm{~min}$. Optimized cox 1 diagnostic primers based on those listed in FishBOL $\left(5^{\prime}-\mathrm{TCA}\right.$ ACY AAT CAY AAA GAT ATY GGC AC-3'; 5'-ACT TCY GGG TGR CCR AAR AAT CA-3') were provided 
by Applied Food Technologies (AFT) (Alachua, FL, USA) [37]. PCR reactions $(20 \mu \mathrm{l})$ were carried out using 1.25 units GoTaq Hot Start Polymerase, $1 \times$ buffer with $1.5 \mathrm{mM} \mathrm{MgCl}_{2}$ (Promega, Madison, WI, USA) and 0.2 mM dNTP Mix (Thermo Fisher Scientific). PCR products were visualized on a $1.5 \%$ agarose $1 \times$ TBE $(89 \mathrm{mM}$ Tris, $89 \mathrm{mM}$ boric acid, $2 \mathrm{mM}$ EDTA, pH 8.6) gel stained with ethidium bromide to confirm target cox 1 amplicons of expected size (540-600 bp).

ExoSAP-IT (Applied Biosystems, Foster City, CA, USA) was used to process cox 1 PCR products prior to Sanger sequencing of each sample using the forward and reverse PCR primers indicated above (University of Chicago Comprehensive Cancer Center, DNA Sequencing \& Genotyping Facility). DNA from the tissue of a fish of known species was used as a positive control for PCR amplification and DNA sequence identity. For samples that did not produce a definitive DNA sequence and chromatogram to enable successful host identification, a second PCR was performed using increased purified template DNA (100 ng). For samples whereby sufficient purified DNA template was not available to allow for this second PCR, $10 \mu \mathrm{l}$ of the first PCR reaction provided the template source for reamplification (Table 1).

\section{Host identification}

Geneious R10 (Biomatters Limited, Auckland, New Zealand) software was used to generate a consensus sequence of the forward and reverse cox 1 sequence for each gnathiid blood meal sample analyzed. This consensus sequence was entered into the Basic Local Alignment Search Tool (BLAST) on the National Center for Biotechnology Information (NCBI) website, as well as into the Barcode of Life Data Systems (BOLD) website to determine the host species identity. A $\geq 98 \%$ match to a reference sequence using BLAST was considered a positive species identification. This was performed for gnathiids used to assess host DNA integrity within blood meals $(n=252)$ and to identify unknown hosts $(n=37)$. The forward $\operatorname{cox} 1$ sequence was used to determine the host identity of the remaining wild-fed gnathiids $(n=63)$.

\section{Results}

\section{Host identification success from digested blood meals:} second-stage pranizae

The host fish species, Hypoplectrus puella, was successfully identified from blood meals of second-stage pranizae allowed to digest for up through $48 \mathrm{~h}$ post-feeding (Table 1). Second-stage pranizae preserved at $0 \mathrm{~h}$ postfeeding (08:00 $\mathrm{h}$ collection time following overnight exposure to known host fish), resulted in $100 \%$ successful host identification. For each successive 4-h collection point, the success rates of host DNA species identification was greater than $90 \%$. At $48 \mathrm{~h}$, the host species identification success rate for the second-stage pranizae, dropped to $15.4 \%$ and by $72 \mathrm{~h}$ post-feeding, host DNA was undetectable.

Table 1 Successful PCR and DNA sequencing of host DNA from gnathiid blood meals

\begin{tabular}{|c|c|c|c|c|c|c|c|c|}
\hline \multirow[t]{2}{*}{ Post-feeding (h) } & \multicolumn{4}{|c|}{ Stage 2 pranizae } & \multicolumn{4}{|c|}{ Stage 3 pranizae } \\
\hline & 1st PCR & $N$ & 2nd $P C R^{b}$ & $\mathrm{~N}_{2}$ & $1 s t P C R^{a}$ & $N$ & 2nd $P C R^{b}$ & $\mathrm{~N}_{2}$ \\
\hline 0 & 100 & 10 & - & - & 94.7 & 19 & 100 & 1 \\
\hline 4 & 91.7 & 12 & 100 & 1 & 100 & 22 & - & - \\
\hline 8 & 100 & 13 & - & - & 95.8 & 24 & 95.8 & 1 \\
\hline 12 & 94.1 & 17 & 100 & 1 & 90.5 & 21 & 100 & 2 \\
\hline 16 & 90.5 & 21 & 100 & 2 & 86.4 & 22 & 100 & 3 \\
\hline 24 & 100 & 14 & - & - & 89.5 & 19 & 100 & 2 \\
\hline 48 & 15.4 & 13 & 76.9 & 11 & 100 & 15 & - & - \\
\hline 72 & nd & nd & nd & & 87.5 & 24 & 100 & 3 \\
\hline 96 & nd & nd & nd & & 84.6 & 13 & 100 & 2 \\
\hline 120 & nd & nd & nd & & 55 & 20 & 100 & 9 \\
\hline
\end{tabular}

Notes: Percent successful identification of fish host species Hypoplectrus puella, using $50 \mathrm{ng}$ of DNA template extracted from gnathiid blood meals in 1 st PCR, at each preservation time interval (post-feeding. in $\mathrm{h}$ ) for second- and third-stage pranizae. Percent successful identification of host species after increasing DNA template or reamplification of PCR products ( 2 nd PCR), performed only on samples that did not amplify using 50 ng template DNA

a The percent successful host identification after the first PCR

b The percent successful host identification after the second PCR

Abbreviations: $N$, the total number of samples at each time point; $N_{2}$, number of samples requiring a reamplification of PCR amplicon or increase in template DNA concentration; nd, not determined 


\section{Host identification success from digested blood meals: third-stage pranizae}

The host fish species, Hypoplectrus puella, was successfully identified from blood meals that had been digested by third-stage pranizae for up to $120 \mathrm{~h}$ post-feeding (Table 1). The third-stage pranizae preserved immediately upon removal from host had a $94.7 \%$ host identification, and remained $\geq 86.4 \%$ over the first $48 \mathrm{~h}$ assessed. DNA extracted from gnathiid digested blood meals $72 \mathrm{~h}$, $96 \mathrm{~h}$, and $120 \mathrm{~h}$ post-feeding showed an expected progressive decrease in host identification success rates of $87.5 \%, 84.6 \%$, and $55.0 \%$, respectively. Seven third-stage pranizae metamorphosed into adult males during these trials, and the DNA within their blood meals was successfully amplified for host identification.

\section{Impact of PCR template DNA concentration on host identification success}

Interestingly, significant gains in host identification success could be attained with select samples when increased amounts of template DNA were used for cox 1 PCR. At the 48-h time interval, successful host identification of second-stage pranizae rose significantly from $15.4 \%$ to $76.9 \%$. The third-stage pranizae analyzed under these reaction conditions resulted in nearly $100 \%$ successful host identification in samples up through 5 days post-feeding. For all time points assessed up to $24 \mathrm{~h}$ for both second and third-stage pranizae, doubling the DNA template used for PCR and reamplification of PCR amplicons, notably achieved $100 \%$ successful host identification (Table 1).

\section{Success of host identification from wild-fed gnathiids}

Of the 100 gnathiids (stage 2-3) with unknown hosts analyzed, a BLAST search resulted in a positive host identification for $69 \%$ of samples. All positively identified hosts were fishes, representing ten families (see Additional file 1: Table S1). The remaining $31.0 \%$ of samples did not receive a $\geq 98 \%$ match to a sequence in GenBank. Of these samples, 25 samples loosely matched to an invertebrate species.

In order to confirm the diagnostic primers did not detect gnathiid DNA, we attempted to amplify purified DNA from 18 third-stage unfed zuphea. These 18 gnathiids were previously fed at stage Z2 using a fish of known species (Hypoplectrus puella) and allowed to digest their blood meal for 5-6 days while metamorphosing into stage Z3. DNA extracted from these samples was used to test for PCR amplification of gnathiid DNA using cox 1 universal fish primers. Fifteen of these gnathiids did not produce a PCR amplicon. DNA was amplified from only three of the zuphea, with sequences matching to the known host fish Hypoplectrus puella.

\section{Discussion}

This study provides a systematic approach to understanding the stability of DNA in blood meals of Gnathia marleyi essential for developing a reliable and reproducible molecular diagnostic for gnathiid host identification. As first-stage pranizae are difficult to collect in the field, and blood meals are small, we focused on second and thirdstage pranizae. While host identity can be determined up to $120 \mathrm{~h}$ post-feeding from third-stage juvenile blood meals and adult males, blood meals sourced from second-stage pranizae were most reliable as template when preserved during the first $24 \mathrm{~h}$ of gnathiid collection. This shorter window for preserving second-stage pranizae could be due to the notable differences in blood meal volume recovered at each of these juvenile stages. For the species used in this study, the final and largest blood meal (P3) in a gnathiid's life is approximately $1 \mu \mathrm{l}$, whereas second-stage pranizae tend to obtain blood meals of less than $0.3 \mu \mathrm{l}$ [27]. Another factor that may contribute to the shorter preservation window of second-stage pranizae is possible differences in gut chemistry among juvenile gnathiid stages. However, further studies are needed as proteolytic activity has only been measured for the gut of third-stage juvenile gnathiids (Paragnathia formica) [41].

While molecular-based host identification of second-stage pranizae is best determined from specimens collected within $24 \mathrm{~h}$ of trap retrieval, accurate host identification greater than $75 \%$ can still be attained from samples collected up through $48 \mathrm{~h}$ post-feeding. This degree of host DNA stability is surprising given that in other blood-feeding arthropods, like mosquitoes, host identification reduces to less than half within $30 \mathrm{~h}$ postfeeding, using similar methodologies [31, 39]. Considering collection logistics in the field and the need to collect thousands of specimens for ecologically-relevant studies, using $24 \mathrm{~h}$ as a cut-off for specimen preservation is a workable timeframe. It should be noted that the methods developed herein were designed to identify hosts of a Caribbean gnathiid isopod. While these methods are applicable to other gnathiid species, the retrieval times and metabolic (and hence host DNA digestion) rates may vary for specific gnathiid species. Gnathiids from polar regions, for example, require two years to complete their life-cycle [42].

Processing logistics for field collection of gnathiid specimens is an important consideration. Due to some restrictions at certain field sites, traps must be set at dusk and allowed to remain on the reef overnight and retrieved the following morning. The $0 \mathrm{~h}$ time point was thus set at 08:00 $\mathrm{h}$ to simulate the anticipated trap collection and processing time during field collection of a gnathiid, having detached from its host and immediately 
entered a light trap prior to its collection. As the gnathiid species used in this study (G. marleyi) molt to the next Z-stage (in the case of P1 and P2 larvae), or to an adult (in the case of P3 stage) in 5-6 days, all pranizae collected in light traps would be $2-120 \mathrm{~h}$ post-feeding. Because there is no control over the amount of time passed from gnathiid-host detachment to the gnathiid entering the light trap, we analyzed the feasibility of host identification from gnathiid blood meals which had been digested for up to $120 \mathrm{~h}$.

The DNA extraction method described consistently produced extractable DNA of sufficient quality and quantity to accommodate 2-3 PCR reactions, based on using $50 \mathrm{ng}$ of DNA template (Hendrick, unpublished data). While template concentration needed to be doubled or reamplified with select samples, the 50 ng DNA template concentration resulted in good overall host identification for the majority of the samples analyzed. Thus, the fish cox 1 primers used are quite sensitive considering the finite quantity of fish host DNA present within the total extracted DNA composed primarily of gnathiid source. These findings validate the described method delivering sufficient quantity and quality of cox1 amplicon for reproducible and accurate fish host identification in future investigations focused on blood meal sourced from wild-caught gnathiids.

DNA sequencing of gnathiid blood meals has previously been used for host identification of two other gnathiid species from the Great Barrier Reef [43, 44]. However, as field parameters (e.g. temperature) and host diversity may impact performance of our molecularbased host species identification method, we conducted a small validation study with wild-caught samples. While only $69 \%$ of samples $(n=100)$ resulted in a $\geq 98 \%$ match to a fish host, our method resulted in significantly better sensitivity than previous reported methods resulting in a host species match $\geq 98 \%$ for only $21.7 \%$ of samples [44]. It is important to note that the successful host identification in both studies is dependent on the availability of reference sequences in public databases.

The lower fish host identification success rate (69.0\%) we observed in comparison to the controlled feeding study with known host fish is likely due to a combination of factors. Blood meal volume could be affected by the ease to which gnathiids attach to specific hosts. In particular, when gnathiids feed in the wild, environmental factors or behaviors of the host may influence the volume of the blood meal obtained and possibly lower the amount of DNA template recovered for molecular analyses. In addition, host behaviors, including rubbing against objects, could cause the gnathiid to detach prematurely and thus reduce total blood meal volume intake. These behaviors have been reported for multiple species of fishes in response to ectoparasite exposure [45-47]. The $>3$-fold lower average concentration of DNA recovered from wild-fed gnathiids $(10.8 \pm 4.7 \mathrm{ng} / \mu \mathrm{l} ; n=37)$ compared to extracted DNA from gnathiids collected at $0800 \mathrm{~h}$ during our controlled experiments $(37.3 \pm 30.2 \mathrm{ng} / \mu \mathrm{l} ; n=19)$ corresponds to these previous studies.

The physical conditions within lighted plankton traps could also play a role in the degradation of host DNA during field collection. It is important to note that during our controlled experimental feeding study, only blood meals from gnathiids that were alive (gnathiids were seen swimming in a Petri dish under a stereomicroscope) at the time of preservation were analyzed. Gnathiid mortality prior to preservation may contribute to an accelerated DNA degradation rate. Light traps attract multiple types of zooplankton and trap "loads" can often be heavy. This in turn can lead to rapid oxygen depletion within the trap, and ultimately death of the contents by asphyxiation. To mitigate this, traps can be fitted with "ventilation" holes at the end opposite the light and/or by the addition of oxygen tablets. Upon collection of the light traps, the contents can be emptied into an aerated container, during transport and while awaiting processing, to further address problems associated with high plankton loads.

In the controlled feeding study, a barred hamlet (Hypoplectrus puella), a highly susceptible host of Gnathia marleyi, was used to validate the host sequence identification in this study. However, gnathiids infect a broad range of fish hosts with some species being more susceptible or heavily exploited than others [17, 40, 44]. While our field validation study, along with existing observational data, suggest that fish are the primary host of this marine ectoparasite, we have observed gnathiid isopods attaching to invertebrates collected in lighted plankton traps, such as chaetognaths and small polychaetes. Interestingly, $25 \%$ of blood meal sequences from wild-caught gnathiids showed probable alignment to invertebrate species, such as those listed above, although matches to sequences in BLAST were much lower than $98 \%$. While feeding on invertebrate hosts could be due to the artificial environment caused by trapping gnathiids and other invertebrates within a light trap, further studies are needed.

In a previous study identifying fish hosts of gnathiids on the Great Barrier Reef, $12 S$ rDNA primers were found to loosely match to invertebrate species within the order Diptera. However, it was stated that these sequences could potentially be from the gnathiids themselves [43]. To test the possibility of amplifying gnathiid DNA using our cox 1 primers, specifically designed to amplify fish DNA, DNA was purified from unfed juvenile gnathiids 
(zuphea). Although the sample group is small, three samples from newly metamorphosed third-stage zuphea exclusively amplified the known fish host DNA, likely due to an incomplete metamorphosis. No other zuphea samples tested $(n=18)$ resulted in amplification of host fish or invertebrate DNA, validating no primer cross reactivity with gnathiid DNA. Ongoing efforts to develop new invertebrate specific cox 1 primers will enable more definitive invertebrate host species identification.

A small subset of the analyzed wild-fed gnathiids ( 6 of $100)$, did not result in a BLAST match that may be due to absence of other fish cox 1 sequences from this public database. Alternatively, insufficient quantity and/or quality of host DNA was recovered to generate a detectable sequence or readable chromatogram.

\section{Conclusions}

To our knowledge, this is the first study to methodically examine, under controlled conditions, the integrity of host DNA over time within gnathiid isopod blood meals, in efforts to deliver an accurate, reproducible, and robust molecular diagnostic tool for fish host identification. Further testing in a small field study supports the use of our molecular-based procedure for future field projects. A very interesting finding from this preliminary field study is that G. marleyi also seems to exploit non-fish hosts, which supports observational data from our team. Therefore, future sampling efforts and analyses will include developing additional diagnostic primer sets in efforts to correctly identify the diversity of gnathiid isopod hosts. To determine the breadth of hosts used by various species of gnathiids in coral reef environments, where host diversity is high, this systematic degradation study of gnathiid blood meals establishes important metrics to inform sample collection and handling techniques. By determining the full range of gnathiid isopod hosts, we can gain insight into host-parasite interactions that contribute to the overall health of host populations and coral reef communities.

\section{Additional file}

Additional file 1: Table S1. List of host species identified using blood meals from wild-fed gnathiids. The list includes both common names and scientific names for identified hosts of Gnathia marleyi, as well as the accession numbers of GenBank reference sequences.

\section{Acknowledgements}

We thank the staff of the MacLean Marine Science Center of University of the Virgin Islands, Arkansas State University, Arkansas Biosciences Institute, and the University of Puerto Rico. We would like to thank M. Nicholson, E. Brill, T. R. Santos, A. Hook, A. Pagan, B. Velez, A. Packard, and O. Rullan for assisting in the deployment of lighted plankton traps to collect wild gnathiids. This project was funded by the National Science Foundation (Grant \#: OCR-1536794, PCS, $\mathrm{Pl})$.

\section{Authors' contributions}

GCH, MCD, TM and PCS all conceptualized this study. GCH preserved gnathiid isopods and performed all molecular work in the laboratory of MCD. All authors read and approved the final manuscript.

\section{Funding}

This project was funded by the National Science Foundation (Grant \#: OCR1536794 to P(S, PI).

\section{Availability of data and materials}

Data supporting the conclusions of this article are included within the article and its additional file. The sequences generated in the present study were submitted to the GenBank database under the accession numbers MN046177-MN046204.

\section{Ethics approval and consent to participate}

This study was conducted in accordance with Arkansas State University IACUC Protocol \# 778227-1.

\section{Consent for publication}

Not applicable.

\section{Competing interests}

The authors declare that they have no competing interests.

\section{Author details}

${ }^{1}$ Department of Biological Sciences, Arkansas State University, State University, AR 72467, USA. ${ }^{2}$ Arkansas Biosciences Institute, 504 University Loop, Jonesboro, AR 72401, USA

Received: 20 November 2018 Accepted: 15 June 2019

Published online: 24 June 2019

\section{References}

1. Weinstein SB, Kuris AM. Independent origins of parasitism in animalia. Biol Lett. 2016;12:1-5

2. Poulin R. The functional importance of parasites in animal communities: many roles at many levels? Int J Parasitol. 1999;29:903-14.

3. Holmstad PR, Hudson PJ, Skorping A. The influence of a parasite community on the dynamics of a host population: a longitudinal study on willow ptarmigan and their parasites. Oikos. 2005;111:377-91.

4. Wood CL, Johnson PT. A world without parasites: exploring the hidden ecology of infection. Front Ecol Environ. 2015;13:425-34.

5. Hudson PJ, Dobson AP, Lafferty KD. Is a healthy ecosystem one that is rich in parasites? Trends Ecol Evol. 2006;21:381-5

6. Hatcher MJ, Dick JR, Dunn AM. Diverse effects of parasites in ecosystems: linking interdependent processes. Front Ecol Environ. 2012;10:186-94

7. McHugh CP. Arthropods: vectors of disease agents. Lab Med. 1994:25:429-37.

8. Shoeler GB, Wikel SK. Modulation of host immunity by haematophagous arthropods. Ann Trop Med Parasitol. 2001:95:755-71.

9. Skotarczak B, Wodecka B, Rymaszewska A, Adamska M. Molecular evidence for bacterial pathogens in Ixodes ricinus ticks infesting Shetland ponies. Exp Appl Acarol. 2016;69:179-89.

10. Lafferty KD, Kuris AM. Trophic strategies, animal diversity and body size. Trends Ecol. 2002;17:507-13.

11. Klitgaard AB. The distribution and habitats in the North Atlantic of two gnathiid species (Crustacea, Isopoda) and their reproductive biology in the Denmark Strait and north of Iceland. Bioscience. 1997;47:1-32.

12. Smit NJ, Davies AJ. The curious life-style of the parasitic stages of gnathiid isopods. Adv Parasitol. 2004;58:289-391.

13. Tanaka K. Life history of gnathiid isopods-current knowledge and future directions. Plankton Benthos Res. 2007;2:1-11.

14. Quattrini AM, Demopoulos AWJ. Ectoparasitism on deep-sea fishes in the western North Atlantic: in situ observations from ROV surveys. Int J Parasitol Parasites Wildl. 2016:5:217-28.

15. Grutter AS. Spatial and temporal variations of the ectoparasites of seven reef fish species from Lizard Island and Heron Island, Australia. Mar Ecol Prog Ser. 1994;115:21-30 
16. Ferreira ML, Smit NJ, Grutter AS, Davies AJ. A new species of gnathiid (Crusacea: Isopoda) parasitizing teleost from Lizard Island, Great Barrier Reef, Australia. J Parasitol. 2009;95:1066-75.

17. Colie AM, Sikkel PC. An experimental field test of susceptibility to ectoparasitic gnathiid isopods among Caribbean reef fishes. Parasitology. 2013;140:1-9.

18. Grutter AS. Parasite removal rates by the cleaner wrasse Labroides dimidiatus. Mar Ecol Prog Ser. 1996;130:61-70.

19. Grutter AS, Poulin R. Intraspecific and interspecific relationships between host size and the abundance of parasitic larval gnathiid isopods on coral reef fishes. Mar Ecol Prog Ser. 1998;164:263-71.

20. Arnal C, Côté IM, Morand S. Why clean and be cleaned? The importance of client ectoparasites and mucus in a marine cleaning symbiosis. Behav Ecol Sociobiol. 2001;51:1-7.

21. Whiteman EA, Côté IM. Cleaning activity of two Caribbean cleaning gobies: intra- and interspecific comparisons. J Fish Biol. 2002;60:1443-58.

22. Grutter AS. Parasite infection rather than tactile stimulation is the proximate cause of cleaning behavior in reef fish. Proc $\mathrm{R}$ Soc Lond. 2001;268:1361-5.

23. Sikkel PC, Cheney KL, Cote IM. Is situ evidence for ectoparasites as a proximate cause of cleaning interactions in reef fish. Anim Behav. 2004;68:241-7.

24. Grutter AS, De Brauwer M, Bshary R, Cheney KL, Cribb TH, Madin EMP, et al. Parasite infestation increases on coral reefs without cleaner fish. Coral Reefs. 2017:37:15-24.

25. Lafferty KD, Allesina S, Arim M, Briggs CJ, De Leo G, Dobson AP, et al. Parasites in food webs: the ultimate missing links. Ecol Lett. 2008;11:533-46.

26. Raffel TR, Martin LB, Rohr JR. Parasites as predators: unifying natural enemy ecology. Trends Ecol Evol. 2008;23:610-8.

27. Artim JM, Sellers JC, Sikkel PC. Micropredation by gnathiid isopods on settlement-stage reef fish in the eastern Caribbean Sea. Bull Mar Sci. 2015;91:479-87.

28. Artim JM, Sikkel PC. Comparison of sampling methodologies and estimation of population parameters for a temporary fish ectoparasite. Int J Parasitol Parasites Wildl. 2016:5:145-57.

29. Baird DJ, Sweeney BW. Applying DNA barcoding in benthology: the state of the science. J North Am Benthol Soc. 2011;30:122-4.

30. Ali MA, Gyulai G, Hidvegi N, Kerti B, Al Hemaid F, Pandey AK, Lee J. The changing epitome of species identification-DNA barcoding. Saudi J Biol Sci. 2014;21:204-31

31. Reeves LE, Holderman CJ, Gillett-Kaufman JL, Kawahara AY, Kaufman PE. Maintenance of host DNA integrity in field-preserved mosquito (Diptera: Culicidae) blood meals for identification by DNA barcoding. Parasit Vectors. 2016:9:503.

32. Hebert PD, Cywinska A, Ball SL, deWaard JR. Biological identifications through DNA barcodes. Proc R Soc Lond. 2003;270:313-21.

33. Alcaide M, Rico C, Ruiz S, Soriguer R, Munoz J, Figuerola J. Disentangling vector-borne transmission networks: a universal DNA barcoding method to identify vertebrate hosts from arthropod bloodmeals. PLoS One. 2009;4:e7092
34. Lassen SB, Nielsen SA, Kristensen M. Identity and diversity of blood meal hosts of biting midges (Diptera: Ceratopogonidae: Culicoides Latreille) in Denmark. Parasit Vectors. 2012:5:143.

35. Brugman VA, Hernandez-Triana LM, Prosser SWJ, Weland C, Westcott DG, Fooks AR, Johnson N. Molecular species identification, host preference and detection of myxoma virus in the Anopheles maculipennis complex (Diptera: Culcidae) in southern England, UK. Parasit Vectors. 2015;8:421.

36. Shokralla S, Hellberg RS, Handy SM, King I, Hajibabaei M. A DNA minibarcoding system for authentication of processed fish products. Sci Rep. 2015:5:15894

37. Applied Food Technologies. http://www.appliedfoodtechnologies.com. Accessed 20 Jan 2016.

38. Weigt LA, Baldwin CC, Driskell A, Smith DG, Ormos A, Reyier EA. Using DNA barcoding to assess Caribbean reef fish biodiversity: expanding taxonomic and geographic coverage. PLOS ONE. 2012;7:e41059.

39. Oshaghi MA, Chavshin AR, Vatandoost H, Yaaghoobi F, Mohtarami F, Noorjah N. Effects of post-ingestion and physical conditions on PCR amplification of host blood meal DNA in mosquitoes. Exp Parasitol. 2006;112:232-6.

40. Sikkel PC, Tuttle LJ, Cure K, Coile AM, Hixon MA. Low susceptibility of invasive red lionfish (Pterois volitans) to a generalist ectoparasite in both its introduced and native ranges. PLoS ONE. 2014;9:e95854.

41. Manship BM, Walker AJ, Jones LA, Davies AJ. Characterisation of cysteine proteinase activities in the digestive tract of juvenile Paragnathia formica isopods, ectoparasites of estuarine fish. Mar Biol. 2008;153:473-82.

42. Wagele JW. Aspects of the life-cycle of the Antarctic fish parasites Gnathia calva Vanhoffen (Crustacea: Isopoda). Polar Biology. 1987:8:287-91.

43. Nagel L, Lougheed SC. A simple molecular technique for identifying marine host fish by sequencing blood-feeding parasites. J Parasitol. 2006;92:665-8

44. Jones CM, Nagel L, Hughes GL, Cribb TH, Grutter AS. Host specificity of two species of Gnathia (Isopoda) determined by DNA sequencing blood meals. Int J Parasitol. 2007:37:927-35.

45. Farquharson C, Smit NJ, Sikkel PC. Gnathia marleyi sp. nov. (Crustacean, Isopoda, Gnathiidae) from the eastern Caribbean. Zootaxa. 2012:3381:47-61.

46. Papastamatiou YP. Sharks as cleaners for reef fish. Coral Reefs. 2007;26:277.

47. Grossman A, Sazima C, Sazima I. Rub and move: barracuda (Sphyraena barracuda) use swimming turtles as scraping surfaces in the south-western Atlantic. Mar Biodivers Rec. 2009;2:1-3.

\section{Publisher's Note}

Springer Nature remains neutral with regard to jurisdictional claims in published maps and institutional affiliations.

Ready to submit your research? Choose BMC and benefit from

- fast, convenient online submission

- thorough peer review by experienced researchers in your field

- rapid publication on acceptance

- support for research data, including large and complex data types

- gold Open Access which fosters wider collaboration and increased citations

- maximum visibility for your research: over 100M website views per year

At $\mathrm{BMC}$, research is always in progress.

Learn more biomedcentral.com/submissions 